\title{
Global network community and non-uniform cell density in the macaque brain
}

\author{
Masanori Shimono \\ From The Twenty Third Annual Computational Neuroscience Meeting: CNS*2014 \\ Québec City, Canada. 26-31 July 2014
}

The important question, how the global network architecture connecting cortical regions keeps balances between integration and segregation of information processes, have been asked to understand the design of the brain $[1,2]$. This study aimed to clarify how topological characteristics of such global network architecture relate with physiological characteristics inside of segmented cortical regions in the monkey brain [3]. Especially, I focused on cell densities (densities of neurons or nonneurons) as the representative characteristics of segmented cortical regions [4], and compared the cell densities with network topologies of cortico-cortical fiber tracts [Figure1-A]. To reduce biases in comparisons, I surveyed many topological measures as wide as possible. Total number of evaluated network measures was 27 .
As the result, surprisingly, only participation coefficient (PCs) showed significant correlations with cell densities [3]. Although a previous study reported that cell densities significantly change on the anterior-posterior coordinate [5], spatial coordinates did not correlate significantly with participation coefficients. Participation coefficient is the topological measure evaluating how often each node (segmented brain region) connects to other nodes locating different communities (modules). The modules, which detected based on a computational criterion [3], corresponded with visual, somatosensory, auditory, and two associative modules [Figure1-C]. The associative modules simultaneously showed low neuron density and high participation coefficient, which means there are diversive connections with different modules. These findings led us to

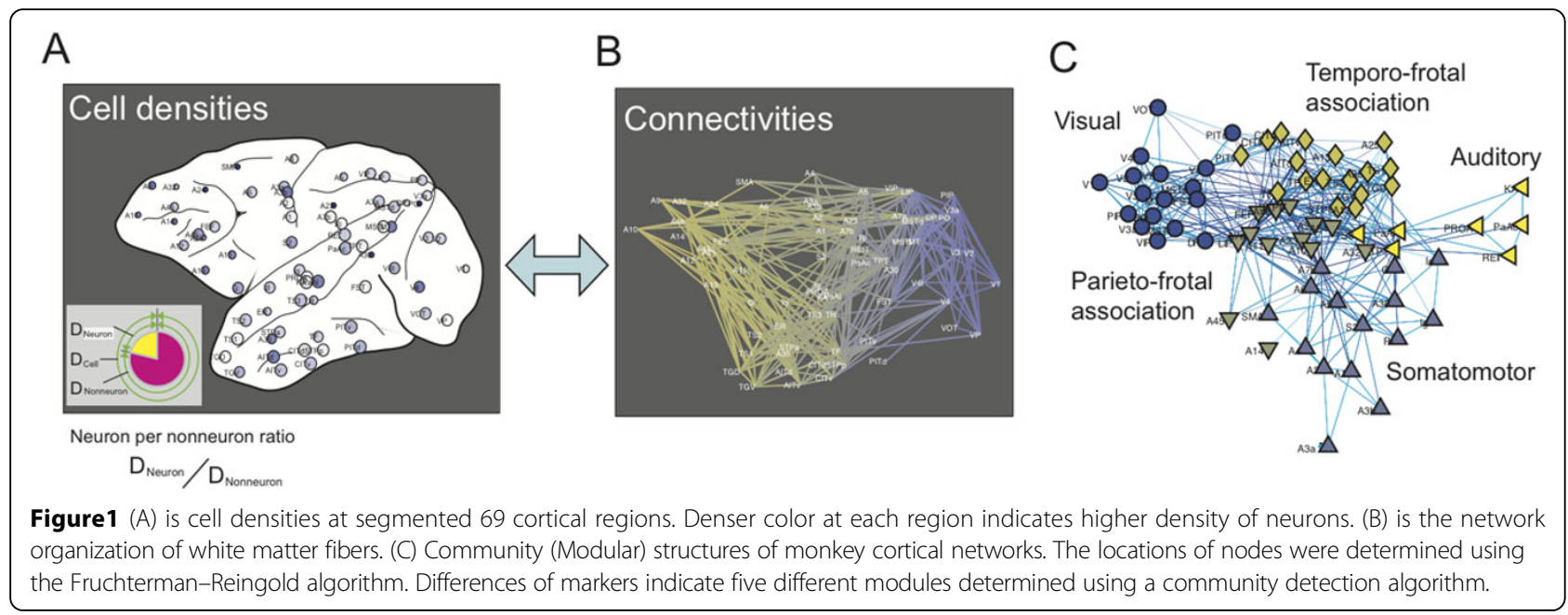

Correspondence: mshimono@indiana.edu

Department of Physics, University of Indiana, Bloomington, IN, 47405, USA

(c) 2014 Shimono; licensee BioMed Central Ltd. This is an Open Access article distributed under the terms of the Creative Commons 
the conclusion that the brain is designed for achieving integrative information process at associative brain regions by sacrificing number of elements (neurons).

\section{Acknowledgements}

M.S. is grateful to Yasuo Kawaguchi, John M. Beggs, and Olaf Sporns for their important discussions. This study was supported by a Grant-in-Aid for JSPS Fellows for Research Abroad.

Published: 21 July 2014

\section{References}

1. Chen Y, Wang S, Hilgetag CC, Zhou C: Trade-off between Multiple Constraints Enables Simultaneous Formation of Modules and Hubs in Neural. PLoS computational biology 2013, 9(3):e1002937.

2. Sporns O: Network attributes for segregation and integration in the human brain. Current opinion in neurobiology 2013.

3. Shimono M: Non-uniformity of cell density and networks in the monkey brain. Scientific reports 2013, 3.

4. Collins CE, Airey DC, Young NA, Leitch DB, Kaas JH: Neuron densities vary across and within cortical areas in primates. Proc Natl Acad Sci USA 2010, 107(36):15927-15932.

5. Cahalane DJ, Charvet CJ, Finlay BL: Systematic, balancing gradients in neuron density and number across the primate isocortex. Frontiers in Neuroanatomy 2012, 6:28.

doi:10.1186/1471-2202-15-S1-P100

Cite this article as: Shimono: Global network community and nonuniform cell density in the macaque brain. BMC Neuroscience 201415 (Suppl 1):P100.

\section{Submit your next manuscript to BioMed Central} and take full advantage of:

- Convenient online submission

- Thorough peer review

- No space constraints or color figure charges

- Immediate publication on acceptance

- Inclusion in PubMed, CAS, Scopus and Google Scholar

- Research which is freely available for redistribution

Submit your manuscript at www.biomedcentral.com/submit
C Biomed Central 